\title{
APLIKASI KONSENTRASI AIR KELAPA TERHADAP PERTUMBUHAN DAN HASIL TANAMAN LOBAK (Raphanus sativus L.)
}

\author{
Alfius Heselo ${ }^{1}$, Sumiyati Tuhuteru ${ }^{2}$ \\ ${ }^{1,2}$ Program Studi Agroteknologi, Sekolah Tinggi Ilmu Pertanian Petra Baliem Wamena, Jl. Sanger, Potikelek, \\ Wamena, Papua 99511 \\ E-Mail: sumiyati.tuhuteru@yahoo.com
}

Receive: 1 March $2019 \quad$ Accepted: 10 April 2019

\begin{abstract}
Radish (Raphanus sativus L.) are tuber-shaped vegetable that contains antibiotics against several types of bacteria and antioxidants. Growth regulators (PGR) are organic compounds other than nutrients that in small amounts can stimulate, inhibit or change pattern of plant growth and development. One of PGR that easily obtained is coconut water. This PGR contains several hormones which are very important for plant growth and development. This study aims to determine effect of coconut water concentration on growth and development of radish and to determine the best concentration of coconut water for growth and yield of radish. The study was conducted with experimental design used was Complete Randomized Completely Block Design (RCBD), which consisted of L0: 0\%; L1: 25\% concentration; L2: 50\%; L3: 75\%; and L4: 100\% concentration. The results showed concentration of coconut water significantly affected growth and yield of radish, namely the observation of 2, 4 and 6 weeks after moving planting (WAMP), parameters of plant height and number of leaves indicated on the observation of 6 WAMP, and weight of radish tubers. Then, the concentration of coconut water that is suitable for growth and yield of radish is a concentration of $50 \%$ and $75 \%$.
\end{abstract}

Key words: Coconut Water, Concentration, PGR, Radish, Rhapanus sativus.

\begin{abstract}
ABSTRAK
Lobak (Raphanus sativus L.) merupakan salah satu sayuran yang berbentuk umbi yang mengandung antibiotik terhadap beberapa jenis bakteri dan antioksidan. Zat pengatur tumbuh (ZPT) adalah persenyawaan organik selain dari nutrien yang dalam jumlah sedikit dapat merangsang, menghambat atau mengubah pola pertumbuhan dan perkembangan tanaman. Salah satu ZPT yang mudah diperoleh adalah air kelapa. ZPT ini mempunyai kandungan beberapa hormon yang sangat penting bagi pertumbuhan dan perkembangan tanaman. Penelitian ini bertujuan untuk mengetahui pengaruh konsentrasi air kelapa terhadap pertumbuhan dan perkembangan tanaman lobak serta Untuk mengetahui konsentrasi air kelapa yang terbaik bagi pertumbuhan dan hasil tanaman lobak (Raphanus sativus L.). Penelitian dilaksanakan pada juni hingga September 2018 dengan susunan rancangan percobaan yang digunakan adalah Rancangan Acak Kelompok Lengkap (RAKL), yang terdiri atas L0: Konsentrasi 0\%; L1: Konsentrasi 25\%; L2: Konsentrasi 50\%; L3: Konsentrasi 75\%; L4: Konsentrasi 100\%. Hasil penelitian menunjukkan konsentrasi air kelapa berpengaruh nyata terhadap pertumbuhan dan hasil tanaman lobak, yakni pada pengamatan 2, 4 dan 6 MSPT parameter tinggi tanaman lobak, dan parameter jumlah daun yang ditunjukkan pada pengamatan 6 MST, serta bobot umbi lobak. Kemudian, konsentrasi air kelapa yang sesuai bagi pertumbuhan dan hasil tanaman lobak adalah konsentrasi $50 \%$ dan $75 \%$.
\end{abstract}

Kata kunci: Air Kelapa, Konsentrasi, Lobak, Rhapanus sativus L, ZPT.

\section{PENDAHULUAN}

Lobak merupakan salah satu sayuran yang berbentuk umbi. Sayur lobak memang jarang digunakan oleh masyarakat umum. Tanaman ini sebetulnya hampir sama dengan wortel akan tetapi apabila wortel berwarna orange, maka lobak berwarna putih. Selain sebagai bahan sayuran, lobak dapat digunakan sebagai obat juga. Hal ini sesuai dengan pendapat Rukmana
(2005) yang mengatakan bahwa Tanaman lobak berkhasiat sebagai obat tradisional. Konon di India dan China, biji lobak digunakan untuk obat masuk angin, memperlancar buang air kecil dan obat menahan pendarahan. Disamping itu menurut kandungan serat pada lobak dapat menekan kolesterol yang menyebabkan serangan jantung (Anonim, 2015).

Sayur lobak mengandung banyak vitamin disamping itu daun lobak juga mengandung beberapa vitamin yaitu vitamin A dan C, 
sementara bijinya mengandung lemak dan minyak astiri. Secara keseluruhan lobak mengandung antibiotik terhadap beberapa jenis bakteri dan antioksidan. Baunya agak menyengat dan rasanya sedikit pedas. Secara umum tanaman lobak memiliki kandungan gizi yang cukup tinggi, yaitu: vitamin A, Vitamin B (B1, B2, B3, $\mathrm{B} 5$, B6, B9), vitamin $\mathrm{C}$, serat, gula, energi, karbohidrat, fosfor, kalsium, magnesium, kalium, lemak, dan protein (Astawan, 2010).

Budidaya sayur lobak dapat berhasil apabila didukung oleh beberapa faktor antara lain pengolahan tanah, pemupukan, dan yang tidak kalah pentingnya adalah dengan pemberian Zat Pengatur Tumbuh (ZPT). Zat pengatur tumbuh (ZPT) adalah persenyawaan organik selain dari nutrien yang dalam jumlah sedikit $(1 \mathrm{mM})$ dapat merangsang, menghambat atau mengubah pola pertumbuhan dan perkembangan tanaman (Moore, 1979; Gunawan, 1995).

Zat pengatur tumbuh pada tanaman adalah senyawa organik bukan hara, dalam jumlah sedikit dapat mendukung, menghambat dan dapat merubah proses fisiologis tanaman (Tuhuteru et al., 2012). Salah satu ZPT yang mudah diperoleh adalah air kelapa. ZPT ini mempunyai kandungan beberapa hormon yang sangat penting bagi pertumbuhan dan perkembangan tanaman.

Air kelapa adalah salah satu diantara beberapa persenyawaan kompleks alamiah yang digunakan dalam meningkatkan pertumbuhan tanaman (Tuhuteru et al., 2012). Morel (1974); Parera (1997), mengatakan bahwa air kelapa menstimulir pembelahan epidermis dan mengarah pada pembentukan protocorm jaringan supaya beregenerasi lebih lanjut dan lebih cepat.

Penggunaan air kelapa sebagai bahan organik merupakan salah satu cara untuk menggantikan penggunaan bahan sintetis yang dipakai dalam pembuatan media kultur, seperti kinetin. Hal ini disebabkan karena, buah kelapa yang mudah diperoleh dan harganya terjangkau lebih murah dibandingkan bahan sintetis yang sulit didapatkan dan harganya yang relatif lebih mahal. Selain itu, keunggulan air kelapa juga sepadan dengan bahan sintetis yang mengandung sitokinin atau merupakam hormon pengganti sitokinin (Tuhuteru et al., 2012). Air kelapa mempunyai kemampuan untuk mendorong pembelahan sel dan proses deferensiasi. Untuk itu, penulis berinisiatif menggunakan air kelapa sebagai salah satu jenis ZPT dalam meningkatkan pertumbuhan dan hasil tanaman lobak.

\section{Lokasi Penelitian}

\section{BAHAN DAN METODE}

Tempat penelitian dilaksanakan di Kebun Percobaan STIPER Petra Baliem Wamena Kabupaten Jayawijaya. Penelitian dilakukan pada tahun 2018.

\section{Bahan dan Alat}

Bahan yang digunakan adalah benih lobak, air kelapa, polibag, kertas label, sedangkan alat yang digunakan adalah sekop, ember, alat tulis, penggaris, timbangan, gelas ukur, baki plastik. Metode penelitian yang digunakan berupa percobaan lapangan dan rancangan percobaan yang digunakan yaitu Rancangan Acak Kelompok Lengkap (RAKL). Rancangan perlakuan yang digunakan adalah 1 faktor yang terdiri dari 4 aras konsentrasi air kelapa. Masingmasing perlakuan diulang 4 ulangan (blok), macam perlakuannya adalah : L0 : Konsentrasi 0\% (300 ml air tanpa air kelapa); L1: Konsentrasi $25 \%$ (75 mi air kelapa $+225 \mathrm{ml}$ air); L2: Konsentrasi 50\% (150 ml air kelapa $+150 \mathrm{ml}$ air); L3: Konsentrasi 75\% (225 ml air kelapa + $75 \mathrm{ml}$ air) dan L4: Konsentrasi 100\% (300 ml air kelapa).

\section{Prosedur Pelaksanaan Persemaian}

Tanaman lobak sebelum ditanam disemaikan terlebih dahulu. Sebelum disemai dilakukan proses penyortiran benih. Hal ini dilakukan untuk memperoleh benih yang tergolong sehat dan baik. Kategori benih yang berkualitas air dilihat dari percobaan perendaman benih kedalam air. Apabila benih yang direndam mengalami proses mengambang diatas permukaan baik, maka benih tersebut dinyatakan tidak sehat. Sedangkan, Benih yang berkualitas baik adalah benih yang tenggelam (tidak mengapung) pada saat direndam. Setelah mendapatkan benih yang terbilang sehat. Kemudian benih tersebut disemaikan pada baki plastik yang telah diisi dengan media tanam tanah.

\section{Penanaman}

Setelah melewati proses persemaian dengan kurun waktu \pm 1 minggu, tanaman lobak kemudian sudah dapat dipindahkan ke masingmasing polybag berukuran $20 \times 25 \mathrm{~cm}$ yang telah berisikan campuran tanah. Kemudian, diberi label sesuai dengan perlakuan yang akan diberikan. Penanaman dilakukan pada pagi hari, 
untuk mencegah terjadinya stres pada tanaman. Diketahui bahwa, penanaman baik dilakukan pada saat suhu lingkungan dalam kondisi dingin atau matahari belum menyengat.

\section{Pembuatan Larutan Konsentrasi Air Kelapa}

Air kelapa diperoleh dari pedagang kaki lima yang ada di pasar Wamena, sebanyak \pm 3 Jerigen (15L). Air kelapa yang diambil diketahui berasal dari kumpulan air kelapa yang dibuang oleh pedang pada saat memecahkan buah kelapa yang akan diparut. Sehingga, umur kelapa yang dipakai sebagai sampel percobaan dalam penelitian ini adalah buah kelapa yang telah matang sempurna. Air kelapa yang diambil kemudian diencerkan sesuai konsentrasi yang telah ditetapkan. Pengenceran dilakukan dengan menambahkan air bersih sesuai dengan konsentrasinya.

\section{Pengaplikasian Perlakuan}

Perlakuan dilakukan dengan menyiram tanaman lobak dengan air kelapa pada saat tanaman berumur 1 minggu setelah pindah tanam (MSPT), 3 minggu setelah pindah tanam (MSPT) dan 5 minggu setelah pindah tanam (MSPT). Pemberian perlakuan disesuaikan dengan perlakuan yang telah ditetapkan.

\section{Pemeliharaan}

Proses pemeliharaan tanaman dalam penelitian ini meliputi:

a. Penyiraman; Penyiraman dengan selang waktu dua kali sehari, yakni pada pagi dan sore hari. Namun, hanya dilakukan apabila media tumbuh terlihat mulai kering.

b. Penyiangan gulma; Proses penyiangan dilakuan setiap saat, dengan mencabut setiap rumput atau tanaman pengganggu yang tumbuh disekitar area penanaman. Hal ini bertujuan untuk menghindari adanya persaingan dalam menyerap unsur hara yang terkandung dalam tanah dan terkait penerimaan pencahayaan matahari.

\section{Pengamatan}

Parameter pengamatan dalam penelitian itu terdiri dari parameter pertumbuhan dan parameter hasil. Parameter pertumbuhan terdiri atas perhitungan tinggi tanaman $(\mathrm{cm})$ dan jumlah daun (helai) tanaman lobak. Kedua parameter ini diukur pada saat tanaman berumur 2, 4 dan 6 MSPT. Sedangkan parameter hasil adalah parameter bobot umbi per tanaman (gr) yang diukur pada 12 MSPT.

\section{Analisis Data}

Data hasil pengamatan dianalisis menggunakan analisis sidik ragam (ANOVA), bila hasil uji menunjukkan perbedaan nyata maka analisis dilanjutkan dengan Uji Beda Nyata Terkecil (BNT) pada taraf 5\%.

\section{HASIL DAN PEMBAHASAN}

Hasil penelitian terhadap parameter tinggi tanaman $(\mathrm{cm})$, jumlah daun (helai) dan bobot umbi (gr) tanaman lobak menunjukkan hasil yang bervariasi. Hasil pengamatan parameter tinggi tanaman dan jumlah daun tanaman lobak dapat dilihat pada Tabel 1, sedangkan hasil penelitian terhadap bobot segar umbi dapat dilihat pada Tabel 2.

Tabel 1 menunjukkan pengaruh pemberian air kelapa pada tinggi tanaman dan jumlah daun tanaman lobak pada pengamatan 2, 4, dan 6 minggu setelah pindah tanam (MSPT). Hasil penelitian menunjukkan adanya pengaruh nyata pada parameter tinggi tanaman pengamatan 2, 4 dan 6 minggu setelah pindah tanam (MSPT), dengan nilai tertinggi pada saat tanaman berumur 2 MSPT ditunjukkan oleh tanaman lobak dengan perlakuan L2 $(6,84 \mathrm{~cm})$ yang berbeda nyata dengan perlakuan L4 $(5,15 \mathrm{~cm})$. Sedangkan, pada pengamatan 4 MSPT nilai rerata tertinggi ditunjukkan oleh perlakuan tanaman lobak dengan perlakuan L3 $(11,53 \mathrm{~cm})$ dan berbeda sangat nyata dengan perlakuan L4 $(7,59 \mathrm{~cm})$. Hal yang sama juga ditunjukkan pada saat tanaman berumur 6 MSPT, dimana tanaman lobak dengan perlakuan L3 menunjukkan nilai rerata tertinggi $(19,72 \mathrm{~cm})$ dan berbeda sangat nyata dengan tanaman kontrol (L0). Hasil penelitian tersebut diduga akibat kandungan hormon tumbuh yang ada didalam air kelapa. Dimana, pada umur pengamatan 2 MSPT tanaman lobak membutuhkan asupan hara dan zat pengatur tumbuh yang belum terlalu optimal, sehingga konsentrasi $50 \%$ (L2) merupakan konsentrasi terbaik dalam proses pertumbuhan tanaman, yang dapat dilihat juga pada pengamatan 4 dan 6 MSPT. Hal ini menunjukkan, semakin hari pertumbuhan tanaman membutuhkan asupan nutrisi yang tinggi. Jika pada pengamatan 2 MSPT sebelumnya menunjukkan rerata tertinggi, maka pada 4 dan 6 MSPT terlihat respon yang nyata oleh tanaman yang diberi perlakuan L3 atau konsentrasi air kelapa sebanyak $75 \%$ dengan perbandingan $225 \mathrm{ml}$ air kelapa ditambahkan dengan $75 \mathrm{ml}$ air.

Pemanjangan batang terjadi karena adanya proses pembelahan, pemanjangan dan pembesaran sel-sel baru yang terjadi pada maristem ujung batang yang mengakibatkan tanaman bertambah tinggi (Gardner et al., 1985; Widiastoety, 2003; Tuhuteru et al. 2012). Dapat dikatakan bahwa, kandungan auksin dan 
sitokinin dalam air kelapa pada konsentrasi $75 \%$ (L3) mampu merangsang pertumbuhan tanaman pada pengamatan 4 dan 6 MSPT yang diketahui, sifat auksin adalah mendorong perpanjangan sel dengan cara memperbaiki matabolisme dalam pembentukan dinding sel, mendorong pertumbuhan dan pembesaran sel sehingga proses fisiologis tanaman dapat ditunjang. Selain itu, kandungan auksin dan sitokinin yang terdapat dalam air kelapa mempunyai peranan penting dalam pembentukan tunas dan pemanjangan sel dalam pertumbuhan tinggi tanaman.

Tabel 1. Rerata Tinggi dan Jumlah daun Tanaman Lobak pada Pengamatan 2, 4 dan 6 Minggu setelah Pindah Tanam (MSPT)

\begin{tabular}{ccccccc}
\hline & \multicolumn{5}{c}{ Parameter } \\
\cline { 2 - 7 } Perlakuan & \multicolumn{3}{c}{ Tinggi Tanaman (cm) } & \multicolumn{3}{c}{ Jumlah Daun } \\
& $\mathbf{2}$ & $\mathbf{4}$ & $\mathbf{6}$ & $\mathbf{2}$ & $\mathbf{4}$ & $\mathbf{6}$ \\
& MSP & MSP & MSP & MSP & MSP & MSP \\
& $\mathbf{T}$ & $\mathbf{T}$ & $\mathbf{T}$ & $\mathbf{T}$ & $\mathbf{T}$ & $\mathbf{T}$ \\
\hline \multirow{2}{*}{ L0 } & 5,41 & 8,40 & 11,3 & 3,11 & 5,88 & 7,99 \\
& $\mathrm{~b}$ & $\mathrm{~b}$ & $2 \mathrm{c}$ & $\mathrm{a}$ & $\mathrm{a}$ & $\mathrm{d}$ \\
L1 & 6,48 & 7,79 & 12,5 & 2,66 & 6,55 & 9,00 \\
& $\mathrm{a}$ & $\mathrm{b}$ & $0 \mathrm{c}$ & $\mathrm{a}$ & $\mathrm{a}$ & $\mathrm{c}$ \\
L2 & 6,84 & 9,08 & 14,9 & 4,44 & 7,22 & 10,4 \\
& $\mathrm{a}$ & $\mathrm{b}$ & $3 \mathrm{~b}$ & $\mathrm{a}$ & $\mathrm{a}$ & $4 \mathrm{~b}$ \\
L3 & 6,39 & 11,5 & 19,7 & 3,33 & 7,66 & 13,1 \\
& $\mathrm{a}$ & $3 \mathrm{a}$ & $2 \mathrm{a}$ & $\mathrm{a}$ & $\mathrm{a}$ & $1 \mathrm{a}$ \\
L4 & 5,15 & 7,59 & 19,1 & 4,00 & 6,89 & 10,6 \\
& $\mathrm{~b}$ & $\mathrm{~b}$ & $0 \mathrm{a}$ & $\mathrm{a}$ & $\mathrm{a}$ & $6 \mathrm{~b}$ \\
\hline \multirow{2}{*}{ BNT } & 0,84 & 2,37 & 1,89 & - & - & 1,32 \\
\hline
\end{tabular}

Ket.: Nilai pada kolom yang sama yang diikuti huruf yang sama menunjukkan tidak berbeda nyata uji BNT 5\%; L0: Konsentrasi 0\% (300 $\mathrm{ml}$ air tanpa air kelapa); L1: Konsentrasi 25\% (75 ml air kelapa $+225 \mathrm{ml}$ air); L2: Konsentrasi 50\% (150 ml air kelapa $+150 \mathrm{ml}$ air); L3: Konsentrasi 75\% (225 ml air kelapa $+75 \mathrm{ml}$ air); L4: Konsentrasi 100\% (300 ml air kelapa).

Hal ini juga dikemukakan oleh Riny (2014) bahwa, auksin akan memacu sel untuk membelah secara cepat dan berkembang menjadi tunas dan batang. Meskipun hal yang berbeda ditunjukkan pada parameter jumlah daun tanaman lobak, yang mana menunjukkan pemberian air kelapa berpengaruh nyata hanya pada pengamatan 6 MSPT. Sedangkan, pada pengamatan 2 dan 4 MSPT menunjukkan tidak berpengaruh nyata. Hal ini diduga karena keberadaan hormon sitokinin dalam kandungan air kelapa. Menurut George dan Sherrington (1984), bahwa air kelapa dapat digunakan sebagai pengganti hormon sitokinin. Pada tingkat konsentrasi tertentu air kelapa dapat menginisiasi terbentuknya tunas dan daun. Ini disebabkan karena kandungan sitokinin dalam konsentrasi tersebut yang lebih besar dari auksin. Hasil penelitian Weser et al., (1974) dalam Tuhuteru et al., (2012), dihasilkan bahwa apabila dalam perbandingan sitokinin lebih besar dari auksin, maka hal ini akan memperlihatkan stimulasi pertumbuhan tunas dan daun. Sebaliknya, apabila sitokinin lebih rendah dari auksin maka ini akan mengakibatkn stimulasi pada pertumbuhan akar. Sedangkan, apabila perbandingan sitokinin dan auksin berimbang, maka pertumbuhan tunas, daun dan akar akan berimbang pula. Hormon sitokinin bersamasama dengan auksin memberikan pengaruh interaksi terhadap diferensiasi jaringan tanaman (Tuhuteru et al., 2012).

Tabel 2. Rerata Bobot Segar Umbi Tanaman Lobak (gr)

\begin{tabular}{cc}
\hline Perlakuan & Bobot Segar Umbi (gram) \\
\hline L0 & $13,33 \mathrm{e}$ \\
L1 & $25,14 \mathrm{~d}$ \\
L2 & $33,57 \mathrm{c}$ \\
L3 & $58,25 \mathrm{a}$ \\
L4 & $48,11 \mathrm{~b}$ \\
\hline BNT & 6,43 \\
\hline Ket.: Nilai pada kolom yang sama yang diikuti huruf yang \\
sama menunjukkan tidak berbeda nyata uji BNT \\
5\%; L0: Konsentrasi $0 \%$ (300 ml air tanpa air \\
kelapa); L1: Konsentrasi 25\% (75 mi air kelapa + \\
225 ml air); L2: Konsentrasi 50\% (150 ml air kelapa \\
+ 150 ml air); L3: Konsentrasi 75\% (225 ml air \\
kelapa + 75 ml air); L4: Konsentrasi 100\% (300 ml \\
air kelapa).
\end{tabular}

Hal ini kemudian dibuktikan dengan parameter hasil tanaman lobak, yakni bobot umbi yang dihasilkan tanaman lobak menunjukkan bahwa perlakuan air kelapa menunjukkan adanya pengaruh nyata (Tabel 2). Dimana, tanaman lobak dengan perlakuan konsentrasi $75 \%$ (L3) menunjukkan bobot segar umbi terbaik $(58,25$ gr) yang berbeda nyata dengan tanaman lobak tanpa diberi perlakuan (L0). Tingginya bobot umbi pada konsentrasi tersebut disebabkan karena ketersediaan nutrisi yang terkandung pada air kelapa cukup bagi tanaman sehingga akan mempercepat pertumbuhan dan perkembangan tanaman dalam hal ini adalah karbohidrat. Karbohidrat yang digunakan umumnya sukrosa atau glukosa pada konsentrasi $2-3 \%$ air kelapa (Murashige, 1974; Widiastoety et al., 1997). Diduga karbohidrat dari kandungan air kelapa pada konsentrasi $75 \%$ (L3) menunjukkan kandungan optimum sehingga mampu membentuk umbi pada tanaman lobak.

\section{KESIMPULAN}


Hasil penelitian yang diperoleh menunjukkan konsentrasi air kelapa berpengaruh nyata terhadap pertumbuhan dan hasil tanaman lobak. Terlihat pada parameter tinggi tanaman lobak umur 2, 4, dan 6 MSPT dan parameter jumlah daun yang ditunjukkan pada umur 6 MSPT, serta bobot umbi lobak. Konsentrasi air kelapa yang terbaik bagi pertumbuhan dan hasil tanaman lobak adalah konsentrasi 50\% (L2) dan 75\% (L3) atau dengan perbadingan konsentrasi $150 \mathrm{ml}$ air kelapa $+150 \mathrm{ml}$ air dan konsentrasi $225 \mathrm{ml}$ air kelapa $+75 \mathrm{ml}$ air.

\section{DAFTAR PUSTAKA}

Anonim. 2015. Sejarah Singkat Lobak. www.syekhfanismd.lecture.ub.ac.id. Diakses Pada Tanggal 02 Mei 2018.

Astawan. 2010. Lobak Cocok untuk Diet. http://cybermed.cbn.net.id/. Diakses tanggal 29 April 2018.

Gardner, F. P., Pearce, R. B. and Mitchell, R. L. 1985. Physiology of Crop Plant. Lowa State University Press, Ames: 327.

George E. F. dan P. D. Sherrington. 1984. Plant Propagation by Tissue culture. Handbook and Directory of Commercial Laboratories. Exegenetic Limited. England.

Gunawan L. W. 1995. Teknik Kultur In Vitro dalam Hortikultura. Jakarta. Penebar Swadaya.

Moore, T. C. 1979. Biochemistry and Physiology of Plant Hormones. Springer-Verlag. New York. 274p.

Morel G. M. 1974. Clonal Multiplication of Orchid: ScientificStudies. (C.L. Withener, ed) : 169222.

Murashige, T. 1974. Plant Propagation Throught Tissue culture. Ann. Bev. Plant Physiol., 25: 135-166

Parera F. Dj. 1997. Pengaruh Tingkat Konsentrasi Air Kelapa Terhadap Pertumbuhan Dan Perbanyakan Tanaman Anggrek Dendrbium spp Melalui teknik Kultur Jaringan. GOTIJurnal Ilmu Pengetahuan dan Teknologi Universitas Pattimura, Volume 2 April 1997. Ambon.

Riny. 2014. Pengaruh Penggunaan Air Kelapa Terhadap Pertumbuhan Tanaman Sawi. Jurnal Biopendix, 1 (1).

Rukmana. 2005. Bertanam Lobak. Kanisius. Yogyakarta

Tuhuteru S., Hehanusa M. L. dan Raharjo S.H.T. 2012. Pertumbuhan dan Perkembangkan Anggrek Dendrobium Anosmum pada Media Kultur In Vitro dengan Beberapa Konsentrasi Air Kelapa. Jurnal Agrologia 1 (1) : 1-12.

Widiastoety, D., S. Kusumo dan Syafni. 1997. Pengaruh Tingkat Ketuaan Air Kelapa dan
Jenis Kelapa terhadap Pertumbuhan Plantlet Anggrek Dendrobium. J. Hort. 7(3):768-772. Widiastoety, D. dan Purbadi. 2003. Pengaruh Bubur Ubi Kayu dan Ubi Jalar terhadap Pertumbuhan Plantlet Anggrek Dendrobium. J.Hort. 13(1):1-6.. 